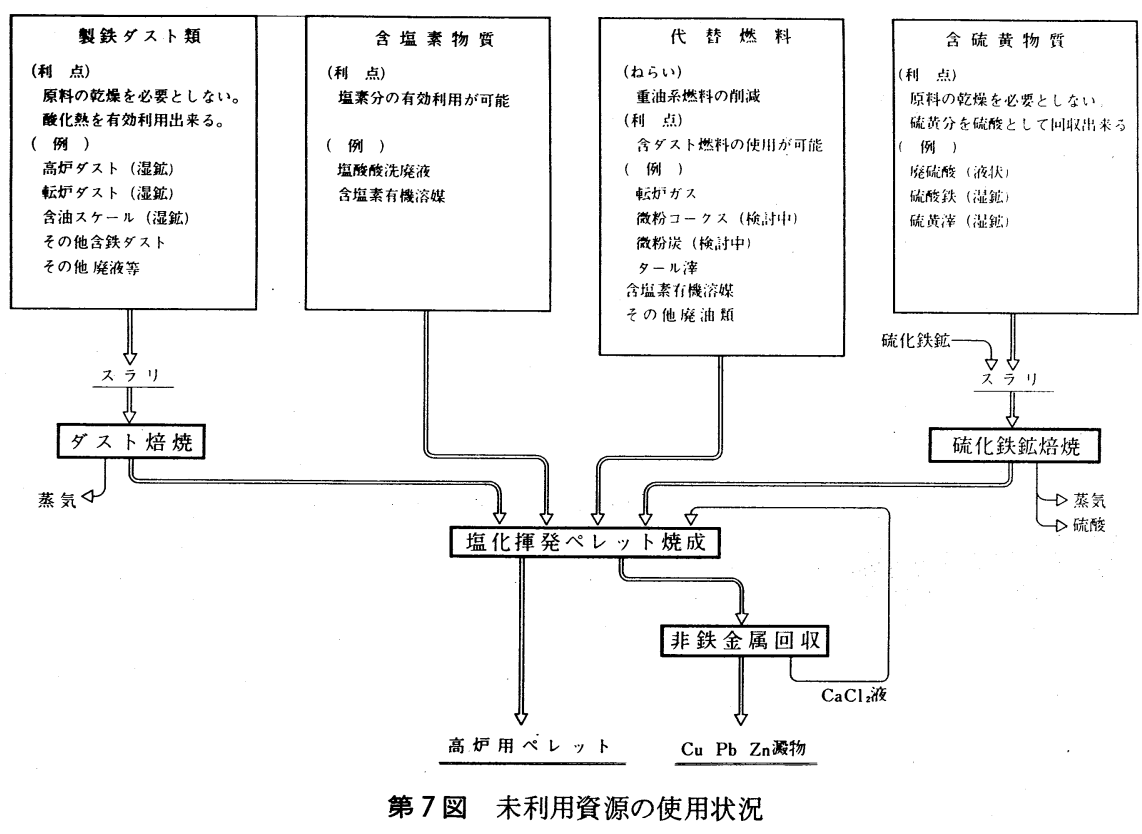

溶解度の低い $\mathrm{Au}, \mathrm{Ag}$ の一部と $\mathrm{Pb}$ の大半は硫酸化物として析出 する。この含金銀硫酸鉛はガス洗浄工程で回収し沪過洗浄後, 鉛 製鍊原料として製鍊所へ送つている。一方，工程溶液は，まず硫 酸分を $\mathrm{CaCO}_{3}$ 中和により $\mathrm{CaSO} 4$ として回収し，次いで銅分は鉄 スクラップ収銅方式により沈殿銅として回収するが，この時溶解 している $\mathrm{Au}, \mathrm{Ag}$ も同時に回収される。残存する亜鉛分およびス クラッブ収銅により溶解した鉄分はそれぞれ $\mathrm{pH}$ 制御により水酸 化亜鉛, 水酸化鉄として回収している。水酸化亜鉛は亜鉛原料と
第 7 表 当所における未利用資源の 使用実績 （昭和54年度）

\begin{tabular}{|c|c|c|}
\hline 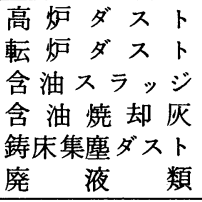 & 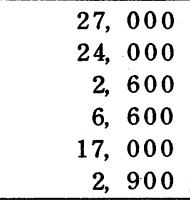 & $\begin{array}{l}t \\
t \\
t \\
t \\
t \\
m^{3}\end{array}$ \\
\hline $\begin{array}{l}\text { 塩酸 廃 液 } \\
\text { 含塩素有機溶剤 }\end{array}$ & $\begin{array}{rr}50, & 000 \\
2, & 200 \\
\end{array}$ & \\
\hline $\begin{array}{lll}\text { 転 } & \text { 师 } \\
\text { 夕 } & \text { 一 } & \text { 涬 } \\
\end{array}$ & $\begin{array}{rr}44,000, & 000 \mathrm{~N} \\
2, & 700 \\
\end{array}$ & $\begin{array}{l}\mathrm{Nm}^{3} \\
\mathrm{t}\end{array}$ \\
\hline $\begin{array}{lll}\text { 廃 } & \text { 硫 } & \text { 酸 } \\
& \text { 酸 } & \text { 鉄 } \\
\text { 硫 } & \text { 黄 } & \text { 涬 }\end{array}$ & $\begin{array}{llll}9, & 0 & 0 & 0 \\
7, & 5 & 0 & 0 \\
4, & 5 & 0 & 0\end{array}$ & $\begin{array}{l}m^{3} \\
t \\
t\end{array}$ \\
\hline
\end{tabular}

して製鍊所へ送つているが，水酸化鉄はぺ レット原料として綝返し使用している。有 価金属を回収した尾夜は稀 $\mathrm{CaCl}_{2}$ 液とな るのでペレットクーラの排熱風を利用し濃 $\mathrm{CaCl}_{2}$ 液として回収している。したがつて 現在は $\mathrm{CaCl}_{2}$ を新規に購入する必要がない。

\section{4. ま め}

以上の結果を要約すれば硫化鉱の完全利用を第一の目的とし てスタートした本プロセスも, その適用範囲を鉄ダスト類の有 効利用にまで拡大するに至り，このことを中心に述べてきた。 さらに一連のプロセス内では過去に廃棄あるいは再資源化されて いなかつた未利用資源の処理も可能であり，その利用状況を第 7 図に示す。今後はさらにこれらの未利用資源の再資源化について, 当プロセスの応用範囲を拡大すべく工程の改善, 設備の増強を進 めていく考えである。

\title{
The Utilization of Wastes Resources at Tobata Plant of Kowa Seiko Co., Ltd.
}

$$
\text { by Ryoichi ASHIYA }
$$

Since May, 1977, the iron bearing dust (flue-dust of blast furnace and/or steel converter sludge, etc.) produced in the Steel Works' has been processed at Tobata Plant with new technics developed by the collaboration with Nippon Steel Corp. and Kowa
Seiko Co., Ltd.

Non-ferrous metals, undesirable impurities for iron manufacturing such as zinc and lead are extracted and recovered from iron bearing dust by this new process.

The new process is the combination of oxidization of iron bearing dust and subsequent pelletizing chlorination process in principle.

\section{〔 3-24〕 昭和電工東長原工場における鉄電解精錬}

\section{1. 緒}

当工場は福島県のほぼ中央部, 会津若松市の近くに位置し, そ の開設は明治 43 年と非常に長い歴史がある。

当工場の主力製品は塩素酸ソーダ, 塩素酸カリ, 電解鉄アトミ

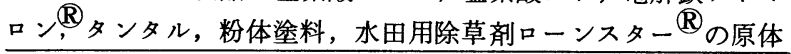

1. 昭和電工株式会社東長原工場次長

2. 昭和電工株式会社東長原工場技術課長

3. 昭和電工株式会社東長原工場技術課

4. 昭和電工株式会社特殊化学品部

$826<226>$

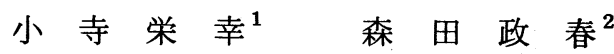

$$
\begin{aligned}
& \text { 南 誠一郎 }{ }^{3} \text { 神谷卓 } \text { 司 }^{4}
\end{aligned}
$$

で，無機，有機，金属といろいろな分野の製品がある。前者 3 製 品は昭和電工 (株), 後者 3 製品はそれぞれ同じ敷地内にある関係 会社, 昭和ケービーアイ(株), 会津コーティング(株), 昭和ローディア化学 （株）で生産されており，合計 300 名の従業員が働いている。

電解鉄は大正 5 年頃, 土橋長兵衛氏が松本市に土橋電気精鍊所 を興し,わが国で初めて電解鉄の精鍊が試みられた。昭和 10 年, この工場は, 松本工場として当社に引継がれ, 昭和 29 年, 塩尻工 場を経て, 昭和 31 年に敷地, 水, 電力の豊富な現在の東長原工場 に移設された。 


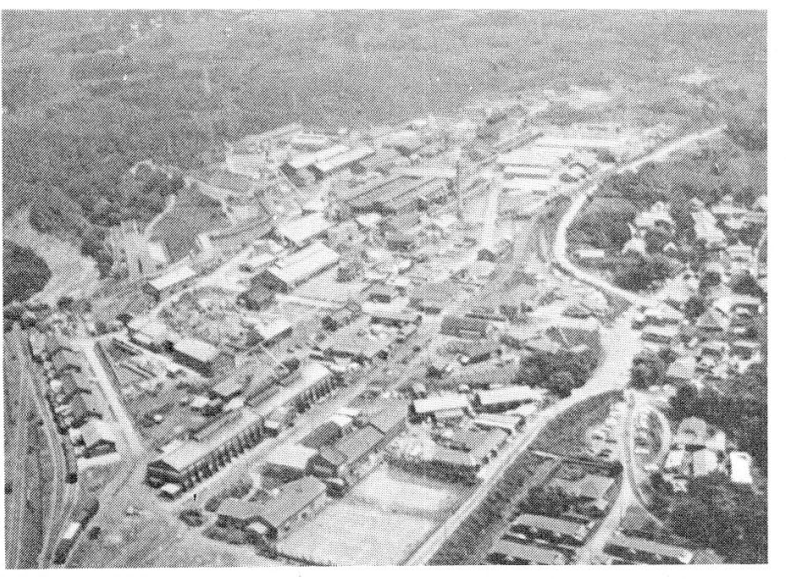

第1図工場 全景

本製品は昭和48年に「アトミロン」という登録商標が付され， 研究開発, 増設を重ね常に業界最高の品質を誇つている。最近で は, 超高張力鋼用に超高純度電解鉄が要求され, 硫黄と燐が 10 ppm以下の製品開発に成功した。また, 他の不純物元素の低減に 挑戦している。不純物含有量が少なく, そのロット内ロット間の バラッキが少ないこと, 使いやすい形状, 溶解時の操作性, さら には加工製品の性能等に秀れた特徵を有し，国内外加高い評価 をうけている。

\section{2. 製 造 万 法}

\section{$2 \cdot 1$ 電解精製}

原料鉄を陽極とし, 適当な鉄塩の水溶液を電解液とし, 陰極に きわめて純粋な鉄を得る。陽極，陰極が同種金属から成り立つて いるので両極の平衡電位は互いに打ち消しあうので, 理論分解電 压はゼ口になる。実際には, 陽極は粗金属であり,陰極も電析後の 不安定な結晶構造をもち分極するので, 純金属の平衡電位より多 少ずれる。したがつて電解電圧はほとんど浴抵抗による電圧降下 のみとなる。

電解精製が行なわれる理由は, イオン化傾向の差による。つま り, 粗金属の中で目的金属よりもイオン化傾向の小さい貴な成分, 不溶性あるいは難溶性物質は溶けずに陽極に付着するか, 槽底に スライムとなつてたまる。イオン化傾向の大きな卑な成分は陽極 からは溶解するが電析電位に達し ないので, 溶液中にイオンの状態 で蓄積する。結局, 陽極から溶解 してきたものの中で, 目的金属の みが電析することになる。したが つて理論上は $100 \%$ 目的金属が 得られるはずである。

しかし, 実際にはイオン化傾向 の小さい成分あるいは不溶性物質 もある溶解度積をもち, わずかで もイオン状態として液中に存在し 電着したり,スライムとして電着 面に巻き込まれたりする。またイ オン化傾向の大きい陽極溶解した 成分も, 不溶性, 難溶性の塩を作 り, スライムとなつて電着面に巻 き込まれたりするので, 純金属を 得るのはむずかしくなつている。 極力, 高純度電解鉄を得るため

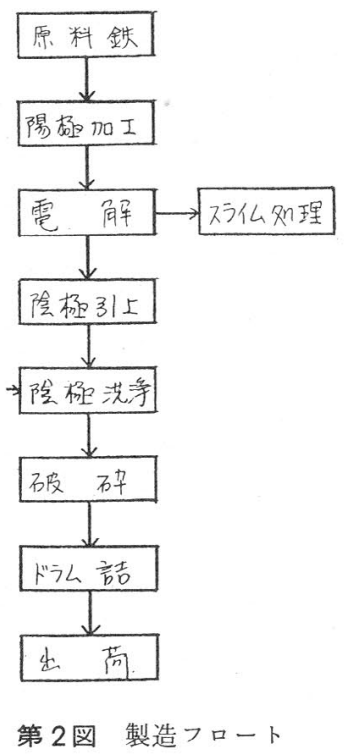

に適正な電解条件, たとえば, $\mathrm{pH}$, 浴温, 電流密度, 電解電圧, 電解浴組成の選定が必要となる。

\section{$2 \cdot 2$ 製造方法}

メインは電解工程であり, コスト, 品質を決定する重要な工程 である。電解鉄製造の際に, 次の二つの問題点がある。

（1）鉄は水素よりも卑な金属であるので, 鉄塩水溶液を電解す れば水素が発生する。

（2）電解浴中の第一鉄イオンが空気により酸化され，第二鉄イ オンになる。これが水酸化物となりスライムとして浴中を浮遊す る。

(1)は水素過電圧があるので実際の水素発生率は 1 割程度である。 (2)は次式より第一鉄イオンが酸化され溶解度積より水酸化第二 鉄が発生する。

$$
\begin{aligned}
4 \mathrm{Fe}^{++}+\mathrm{O}_{2}+4 \mathrm{H}^{+} & \rightleftharpoons 4 \mathrm{Fe}^{+++}+2 \mathrm{H}_{2} \mathrm{O} \\
\mathrm{Fe}^{+++}+3 \mathrm{H}_{2} \mathrm{O} & \sim 2 \times 10^{-8} \ldots(1) \\
\mathrm{Fe}(\mathrm{OH})_{3}+3 \mathrm{H}^{+} & \sim 5 \times 10^{-11 \ldots-(2)}
\end{aligned}
$$
上式を防止するためには, $\mathrm{pH}$, 浴温, 電流密度を下げればいい が水素発生が起こり, 生産性が悪くなる。水素発生が起こると, 電着面は著しい凸凹を呈し, あるいは粗になり黒色粉末になる。 また浮遊スライムは不純物含有量に影響することになる。したが つて古来種々の電解浴組成, 電解条件, 脱ガス方法が提案されて いるが，これらの現象をさけることは不可能である。適当な電着 厚み，不純物含有量を同時に満足させる電解条件の範讲もせまく 非常に厳しい管理が必要とされる。

当社の場合, 初めは硫酸浴により電解を行なつていたが, 不純 物特に S が結晶粒界に析出し, 強度的に悪影響を与えるというこ とから, 昭和 39 年頃 Low S 品として塩酸浴による電解鉄が開発

\begin{tabular}{|c|c|c|c|c|c|}
\hline & \multicolumn{3}{|c|}{ 電 解 浴 組 成 } & 電解条件 & 提 案 \\
\hline 硫 & $\begin{array}{l}\mathrm{Fe} \mathrm{SO}_{4} \cdot 7 \mathrm{H}_{2} \mathrm{O} \\
\mathrm{Mg} \mathrm{SO}_{4} \\
\text { 水 }\end{array}$ & $\begin{array}{r}200 \\
50 \\
1\end{array}$ & & $\begin{array}{r}\text { 常 } \\
0.5 \mathrm{~A} / \\
\mathrm{dm}^{2}\end{array}$ & Klein (1868) \\
\hline $\begin{array}{l}\text { 酸 } \\
\text { 塩 }\end{array}$ & $\begin{array}{l}\mathrm{FeSO} \mathrm{SO}_{4} \cdot 7 \mathrm{H}_{2} \mathrm{O} \\
\left(\mathrm{NH}_{4}\right)_{2} \mathrm{SO}_{4} \\
\text { 水 }\end{array}$ & $\begin{array}{r}150 \\
100 \\
1\end{array}$ & & $\begin{array}{l}30^{\circ} \mathrm{C} \\
1 \mathrm{~A} / \mathrm{dm}^{2}\end{array}$ & $\begin{array}{l}\text { Bürgess, Hambuchen } \\
\text { (1904) }\end{array}$ \\
\hline 浴 & $\begin{array}{l}\mathrm{Fe}\left(\mathrm{NH}_{4}\right)_{2}(\mathrm{SO} \\
6 \mathrm{H}_{2} \mathrm{O} \\
\text { 水 }\end{array}$ & $\begin{array}{r}350 \\
1\end{array}$ & & $\begin{array}{l}60^{\circ} \mathrm{C} \\
\mathrm{pH} 6 \\
2 \sim 7 \mathrm{~A} / \mathrm{dm}^{2}\end{array}$ & Mc Fa dyen (1920) \\
\hline \multirow{4}{*}{$\begin{array}{l}\text { 塩 } \\
\text { 酸 } \\
\text { 塩 } \\
\text { 浴 }\end{array}$} & $\begin{array}{l}\mathrm{FeCl}_{2} \cdot 4 \mathrm{H}_{2} \mathrm{O} \\
\text { 水 }\end{array}$ & $\begin{array}{r}1,000 \\
1\end{array}$ & & $\begin{array}{c}70^{\circ} \mathrm{C}< \\
3 \sim 4 \mathrm{~A} \\
/ \mathrm{dm}^{2}\end{array}$ & Merk (1900) \\
\hline & $\begin{array}{l}\mathrm{FeCl}_{2} \cdot 4 \mathrm{H}_{2} \mathrm{O} \\
\mathrm{CaCl}_{2} \\
\text { 水 }\end{array}$ & $\begin{array}{r}300 \sim 400 \\
300 \sim 500 \\
1\end{array}$ & & $\begin{array}{c}90^{\circ} \mathrm{C}< \\
<20 \mathrm{~A} \\
/ \mathrm{dm}^{2}\end{array}$ & $\begin{array}{l}\text { Fischer \& Langbein } \\
\text { (1909) } \\
\text { Huhgess (1921) }\end{array}$ \\
\hline & $\begin{array}{l}\mathrm{FeCl}_{2} \cdot 4 \mathrm{H}_{2} \mathrm{O} \\
\mathrm{NaCl} \\
\mathrm{HCl} \\
\text { 水 }\end{array}$ & $\begin{array}{r}300 \sim 500 \\
60 \sim 120 \\
1\end{array}$ & & $\begin{array}{c}90 \sim 95^{\circ} \mathrm{C} \\
\mathrm{pH} 2.5 \sim 3 \\
10 \sim 20 \\
\mathrm{~A} / \mathrm{dm}^{2}\end{array}$ & $\begin{array}{l}\text { Fischer \& Langbe in } \\
\text { Siemens \& Halske } \\
\text { A. G. (1918) } \\
\text { 角田 (1929) } \\
\text { Tschäpätt (1949) }\end{array}$ \\
\hline & $\begin{array}{l}\mathrm{FeCl}_{2} \cdot 4 \mathrm{H}_{2} \mathrm{O} \\
\mathrm{HCl}\end{array}$ & $\begin{array}{r}400 \sim 500 \\
0.11\end{array}$ & & $\begin{array}{l}106^{\circ} \mathrm{C} \\
6.5 \sim 20 \\
\mathrm{~A} / \mathrm{dm}^{2}\end{array}$ & Kasper (1937) \\
\hline \multirow{3}{*}{$\begin{array}{c}\text { 硫 } \\
\text { 酸 } \\
\text { 塩 } \\
\text { • } \\
\text { 塩 } \\
\text { 酸 } \\
\text { 塩 } \\
\text { 混 } \\
\text { 合 } \\
\text { 浴 }\end{array}$} & $\begin{array}{l}\mathrm{FeSO}_{4} \cdot 7 \mathrm{H}_{2} \mathrm{O} \\
\mathrm{NH}_{4} \mathrm{Cl} \\
\mathrm{Na} \text { Citrate } \\
\text { 水 }\end{array}$ & $\begin{array}{r}130 \\
100 \\
3 \\
1\end{array}$ & & $\begin{array}{l}15 \sim 20^{\circ} \mathrm{C} \\
0.1 \mathrm{~A} / \mathrm{dm}^{2}\end{array}$ & Pfanhauser \\
\hline & $\begin{array}{l}\mathrm{FeSO}_{4} \cdot 7 \mathrm{H}_{2} \mathrm{O} \\
\mathrm{FeCl}_{2} \cdot 4 \mathrm{H}_{2} \mathrm{O} \\
\mathrm{NH}_{4} \mathrm{Cl} \\
\text { 水 }\end{array}$ & $\begin{array}{r}250 \\
42 \\
20 \\
1\end{array}$ & $\begin{array}{l}\mathrm{g} \\
11 \\
\text { " } \\
l\end{array}$ & $\begin{array}{c}20 \sim 40^{\circ} \mathrm{C} \\
\mathrm{pH} \sim 5 \\
3 \sim 5 \mathrm{~A} \\
\quad / \mathrm{dm}^{2}\end{array}$ & $\begin{array}{l}\text { Schaffert \& Gonser } \\
(1942)\end{array}$ \\
\hline & $\begin{array}{l}\mathrm{FeSO}_{4} \cdot 7 \mathrm{H}_{2} \mathrm{O} \\
\mathrm{NH}_{4} \mathrm{C} 1 \\
\text { 界面活性斉 } \\
\text { 水 }\end{array}$ & $\begin{array}{r}400 \\
150 \\
5 \\
1 \\
\end{array}$ & $\begin{array}{l}g \\
\text { "I } \\
\prime \prime \\
l\end{array}$ & $\begin{array}{c}30 \sim 40^{\circ} \mathrm{C} \\
\mathrm{pH} 5 \sim 6 \\
3 \sim 5 \mathrm{~A} \\
/ \mathrm{dm}^{2}\end{array}$ & 向 正夫（1945） \\
\hline
\end{tabular}

第 1 表

出典「鉄の電解精鍊」向正夫：電気化学, 21, 204～211, (1953) 
された。硫酸浴はモールス塩, 塩酸浴はフィッシャ塩を基礎とし 当社独自の改良を加えたものである。電解夜は循環方式をとつて 扔り, 電解条件のバラッキを防いでいる。管理としては, 定期的 に分析し補鉄あるいは補液を行なつている。

陽極は一定時間電解後, 取りかえる。残基 (電解後の陽極の一 部) は補鉄用の鉄源として再利用している。当初はカゴの中に原 料鉄を入れ陽極としていたが, 現在吊り下げ型をとつている。最 近, 原料鉄の組成が変化してきておうう, 製品中の不純物含有量に も影響が出てきている。

陰極の形状は, 脱ガス方法によつていろいろ变わる。枹打型, あるいは強制循環型ではブレート方式, 他方回転ドラム方式があ る。それぞれ一長一短があり, 当社は後者で行なつている。駆動 方法が問題となるがいろいろ工夫が重ねられ現在に至つている。 電着後引上げ, アルカリ水溶夜で洗浄し破研の後, ドラム缶詰に している。

コストの一部を占める電力費は, 電流効率, 電解電圧で決まり, それらは, $\mathrm{pH}$, 浴温, 第一鉄イオン濃度, 電流密度, 極間距離 によつて決まる。コストダウンを図る場合，電流効率をあげるか， 電解電圧を下げる方向になるが, 良質の電解鉄を得るには, 高浴 温, 高第一鉄イオン濃度, 適性 $\mathrm{pH}$, 低電流密度を維持しなけれ ばならず，保温のための対策はとられているが，大幅な低下は望 めない。極間距離を縮めることも割れ発生を誘引するので限度が ある。現在のようにエネルギーコストが上昇してくると, 製品コ ストへのは初かえりが大きく, 根本的な電解鉄製造の技術革新 が必要になつてきている。

下記に, 電解条件と電力原単位を載せておく。

$$
\begin{array}{ll}
\text { 電流密度 } & 2 \sim 5 \mathrm{~A} / \mathrm{dm}^{2} \\
\mathrm{pH} & 4 \sim 6 \\
\text { 電力原単位 } & 5,000 \sim 7,000 \mathrm{kWh} / \mathrm{t}
\end{array}
$$

\section{3. 不純物の挙動}

電解鉄の特㟨は, その高純度性にある。い かに高純度の安定した, 安価な製品をつくる かが問題となる。当社の場合, 不純物元素の 主要 7 成分 $-\mathrm{C}, \mathrm{S}, \mathrm{P}, \mathrm{Si}, \mathrm{Mn}, \mathrm{Cu}, \mathrm{Cl}(\mathrm{F}$ 品のみ) 一を分析し, スペックを決めている。 定性的になるが, これらの陰極混入形態につ いて次のように考えられる。

(1) $\mathrm{Cu}$ 注陽極溶解せず不純物として液中 に存在する。しかし浴中の銅イオン濃度が， $1 \mathrm{ppm}$ 前後存在することから, 溶出し電着す ることになる。溶出については, 熱化学デー タから推論できる。

(2) $\mathrm{Si}, \mathrm{Mn}$ は陽極溶解する。液中に数 10 $\mathrm{ppm}$, スライム中に数 $100 \mathrm{ppm}$ 存在する。大 部分はスライムとして巻き込まれる。また不 溶物化速度, スライム沈降速度は早いと思わ れる。

(3) P は陽極溶解する。液中に数 ppm，ス ライム中に数 $100 \mathrm{ppm}$ 存在する。浮遊スライ ムが巻き込まれることになるが，これについ ては錯イオンを形成し電着されるという説も ある。 $\mathrm{pH}$, 第一鉄イオン濃度, 電流密度, 電解質等により, その領域が変化するものと

\begin{tabular}{|c|c|c|c|}
\hline 銘 柄 & 品 & F品 (Low S ) & XL品 (Low P.S) \\
\hline 破研品 & $\begin{array}{l}(50 \sim 70) \times(50 \sim 70) \\
\times(10 \sim 13)\end{array}$ & $\begin{array}{l}(50 \sim 70) \times(50 \sim 70) \\
\times(10 \sim 13)\end{array}$ & $\begin{array}{l}(50 \sim 70) \times(50 \sim 70) \\
\times(10 \sim 13)\end{array}$ \\
\hline
\end{tabular}
思われる。不溶物化速度は遅く, 電解条件の 設定によつて変化する。

〈注〉（1）XL品は特殊グレード品として開発されたもの。

(2) 上記以外の破砕品サイズ $(20 \sim 30) \times(20 \sim 30) \times(10 \sim 13)$ もあ。

（4） S 溶液の巻き込みと思われる。

（5） Cは原料中のセメンタイトが原因になると思われる。 $\mathrm{pH}$ が低下すると C 量は增加する傾向がある。

以上の観点から不純物含有量低隇策として, いかにスライム化 速度を速くして, 不純物との塩形成, あるい㹥共沈を促進させる かが問題となる。スライムは極力, 槽底へ沈降させ, 定期的に抜 き出し，処理を行なつている。

\section{4. 特長}

電解鉄は上記のように, 水素発生を伴い厚く電着させることは 相当困難であるが，当社の電解鉄は $10 \mathrm{~mm}$ まで電着させており， 世界でも例をみない。また用途によつてはそれ以上の電着も可能 である。純度についても最高の品質と高い安定性を備えている。

製品はアトミロン ${ }^{\mathbb{R}}-\mathrm{M}$ (硫酸浴)，アトミロン ${ }^{\mathbb{R}}-\mathrm{F}$ (塩酸 浴 )，アトミロン ${ }^{\mathbb{R}}-\mathrm{XL}$ に分けられる。F品は, 製法上塩素を

\begin{tabular}{|c|c|c|}
\hline 銘 柄 & 荷 & 姿 \\
\hline $\mathrm{M}, \mathrm{F}$ 品 & $50 \mathrm{~kg}$ 鉄製 ドラム詰 ( & $3.0 \sim 3.3 \mathrm{~kg} /(l)$ \\
\hline $\mathrm{X}$ L 品 & $25 \mathrm{~kg}$ 鉄製ドラム詰 ( & " \\
\hline
\end{tabular}

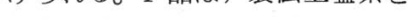

荷 姿

\begin{tabular}{|c|c|c|c|c|c|c|c|c|}
\hline \multicolumn{8}{|c|}{ 第 5 表 製品の参考分析値 } & 重量 \% \\
\hline 成分名 & $\mathrm{M}$ 品 & $\mathrm{F}$ 品 & 成分名 & $\mathrm{M}$ 品 & $\mathrm{F}$ 品 & 成分名 & $\mathrm{M}$ 品 & $\mathrm{F}$ 品 \\
\hline Al & 0.003 & 0.002 & $\mathrm{Cr}$ & 0.002 & 0. 002 & $\mathrm{~Pb}$ & $<0.001$ & $<0.001$ \\
\hline As & N. D & N.D & $\mathrm{H}$ & 0.0042 & 0.0024 & Sn & 0.006 & 0.005 \\
\hline $\mathrm{B}$ & $<0.001$ & $<0.001$ & $\mathrm{Mg}$ & 0.00017 & 0.00014 & $\mathrm{~V}$ & N. D & N.D \\
\hline $\mathrm{Ba}$ & $<0.0005$ & 0.0015 & Mo & $<0.001$ & $<0.001$ & W & $<0.001$ & $<0.001$ \\
\hline $\mathrm{Cd}$ & $<0.00002$ & 0.00009 & $\mathrm{~N}$ & 0.003 & 0.005 & $\mathrm{Zn}$ & $<0.001$ & $<0.001$ \\
\hline $\mathrm{Cl}$ & - & 0.045 & $\mathrm{Ni}$ & 0.007 & 0.001 & $\mathrm{Zr}$ & $<0.0005$ & $<0.0005$ \\
\hline $\mathrm{Co}$ & 0.005 & 0.004 & $\mathrm{O}$ & 0.050 & 0.035 & & & \\
\hline
\end{tabular}

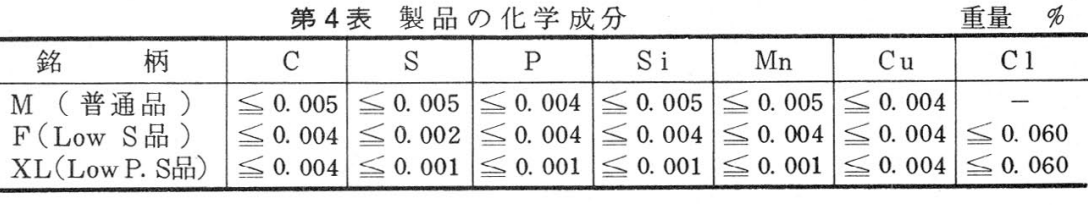

ND：検出せず 


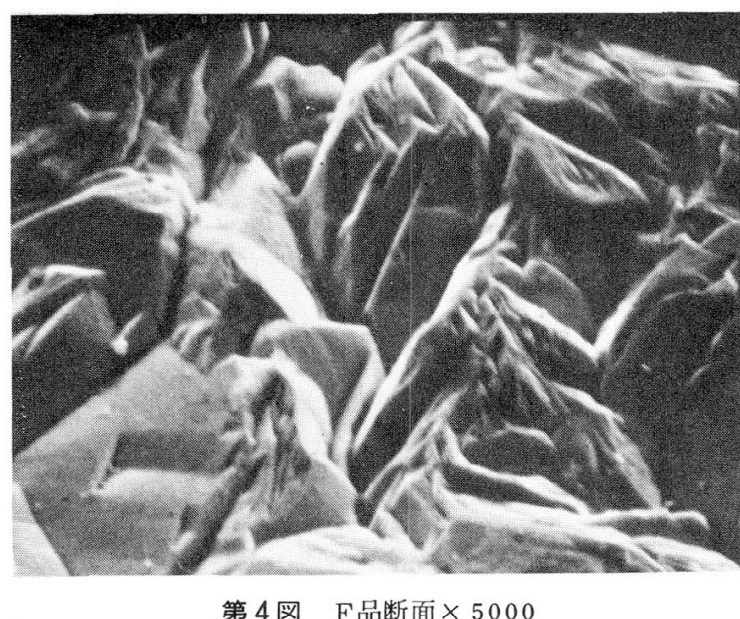

含むが, メタル溶解時容易に飛散し, 高浴温なので水素含量も少 なく軟かい。また前者は電流密度が低い点で結晶構造上粒子が粗 く, 整然としており錆にくい。

当社の製品のサイズ, 荷姿, 化学成分, 参考分析値を第 2 表, 第 3 表，第 4 表，第 5 表に示す。その他に特に高品位の成分品を 希望される場合には, 相談に応じている。

\section{5. 用途}

（1）研究用ベースメタル 不純物質がきわめて少なくかつ 品質安定, 各成分のバランスも良く取扱いも容易なため, ベース メタル用として超抗張力鋼 (マルエイジ鋼), 耐熱鋼等鉄鋼関係 の研究用に使われている。

（2）磁性材料高級磁性材料製造時の原料鉄源として, 78.5 $\% \mathrm{Ni}$ パーマロイ（ $\mathrm{PC}$ 材），80 $82 \% \mathrm{Ni}$ パーマロイ等に用い られ，製品の安定性も良く，高性能，長寿命は定評がある。

また, アトミロン®粉化調整, 酸化して得られる高純度の酸化 鉄は, 磁性特性の良好なフェライトとなり電子材料等に使用され る。

そして，最近この方面では新しい磁性合金の用途開発も進み， アトミロン®の利用も増加している。

（3）特殊合金原料 超抗張力鋼等, 高度の特性を要求され る鉄合金の原料として利用される。

その他，耐熱鋼，耐食鋼（超低温，超高圧容器）用に供される。 （4）不純物稀䣋材 特殊溶接棒 特定金属成分の稀䣋用と して(超低炭素フェロクローム等)，あるいは特殊合金用溶接棒

\begin{tabular}{c|c|c|c|c|c|c|c}
\multicolumn{9}{c}{ 第 6 表 XL品の参考分析値 } & \multicolumn{1}{c}{ 重量 \% } \\
\hline 成分名 & 分析値 & 成分名 & 分析値 & 成分名 & 分析值 & 成分名 & 分析値 \\
\hline $\mathrm{C}$ & 0.0040 & $\mathrm{Al}$ & 0.0005 & $\mathrm{Ba}$ & $<0.0002$ & $\mathrm{~W}$ & $<0.001$ \\
$\mathrm{~S}$ & 0.0001 & $\mathrm{Ni}$ & 0.0004 & $\mathrm{Mo}$ & 0.0008 & $\mathrm{~V}$ & $<0.001$ \\
$\mathrm{P}$ & 0.0004 & $\mathrm{Co}$ & 0.0010 & $\mathrm{Mg}$ & $<0.0002$ & $\mathrm{~T} \mathrm{i}$ & $<0.001$ \\
$\mathrm{~S} \mathrm{i}$ & 0.0003 & $\mathrm{~Pb}$ & $<0.0002$ & $\mathrm{Ca}$ & $<0.0002$ & $\mathrm{Zr}$ & $<0.001$ \\
$\mathrm{Mn}$ & 0.0002 & $\mathrm{Zn}$ & 0.0003 & $\mathrm{~B}$ & $<0.0001$ & & \\
$\mathrm{Cu}$ & 0.0008 & $\mathrm{Cr}$ & $<0.0002$ & $\mathrm{As}$ & $\mathrm{N} . \mathrm{D}$ & & \\
$\mathrm{Cl}$ & 0.026 & $\mathrm{Sn}$ & $<0.001$ & $\mathrm{~B} \mathrm{i}$ & $<0.0002$ & & \\
$\mathrm{~N}$ & 0.0055 & $\mathrm{Cd}$ & $<0.0002$ & $\mathrm{Sb}$ & $<0.0002$ & & \\
\hline
\end{tabular}

（LNG 関係構造物の加工用）に利用される。

（5）触媒 アルカリ二次電池原料触媒としては，機械的 強度が高く高性能のものが得られる。電池としては, アトミロ・R 粉は針状で見掛密度が低く $2.3 \sim 2.7 \mathrm{~g} / \mathrm{cc}$ ), 比表面積が大き くアルカリ電池の陰極として適する。

（6）顔料, 化粧品, 医薬, 食品添加用原料有害成分がき わめて少なく上記各種原料に使用されている。

（7）分析用標準試料, 助燃材用各大学, 研究室における 鉄分析試料および助然材として使用される。

（8）粉末冶金 特に高密度, 高負荷を要求される部品の製 造用として, アトミロン $(\mathbb{R}-F$ の鉄粉は圧粉密度か゚高く $(7.2 \mathrm{~g} /$ cc : $\left.5 \mathrm{t} / \mathrm{cm}^{2}\right)$, 自動車用を中心とした機械部品に利用される。

（9）その他 マグナ探傷用磁粉として金属部品や構造物の 探傷用等, 数多くの分野に利用される。

$$
\text { 6. 結言 }
$$

近年乾式精鍊の技術進歩が著しく純度の面でアトミロン®に近 づいてきている。その乾式精鍊技術でもどうしても抜けない不純 物あるいは抜けたとしても, 非常にコスト高になる元素, たとえ ば S, P, B , N , O , Cl , Co 等については, 電解精鍊が非常に役に 立つ手段と思われる。一工程で不純物含有量の低減が可能と思わ れる。中でもリンについては, 乾式法で 20 ppmが限度であるが, 当社で $10 \mathrm{ppm}$ 以下の製品開発に成功し, Low $\mathrm{P}, \mathrm{S}$ の特性をも つたXL品として販売を始めた。

電解鉄の将来性について，新電解方法，添加剤，用途開発，物 性の研究とまだ多くの課題が残されており, 最近の合金物性の進 歩，分析技術の進歩と伴に一層の高純度化が要求され，発展する と思われる。乾式精鍊で得られない高品質, ニーザーの希望通り の品質を達成すべく，一層の努力を続けていく所存である。

\section{Iron Electrorefining at Showa Denko's Higashinagahara Works}

\section{by Eikou KODERA, Masaharu MORITA, Seiichirou MINAMI and Takushi KAMIYA} iron.

Atomiron, an electrolytic iron manufactured by Showa Denko at its Higashinagahara Works, is obtained by electrorefining ments.

During the sixty years since its debut, the facilities for its production have undergone extensive expansions and improve-

Application of a unique rotary cathode process, which Showa Denko developed by integrating its traditional technology with innovations of its own, enables the company to supply high purity electrolytic iron of a thickness of more than $10 \mathrm{~mm}$ Atomiron comes in three grades: M (standard), F (low sulfur) and XL (specialty). Of these grades, the newest is XL, which has a sulfur and a phosphorous content of $10 \mathrm{ppm}$ maximum each.

Since it has uniform composition intra-lot and inter-lot, a low impurities content and a shape that makes it easy to handle at melting time, Atomiron is highly evaluated at home and abroad for the advantages it offers in applications such as metal for research and Fe source for specialty metals. 